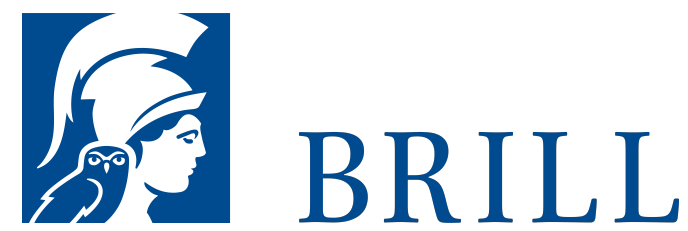

\title{
Sollen ohne Können?
}

Über Sinn und Geltung nicht erfüllbarer Sollensansprüche

Author: Michael Kühler

Wie sinnvoll ist es, von Akteuren etwas zu fordern, wenn sie der Forderung nicht nachkommen können? Angesichts des weithin anerkannten Prinzips „Sollen impliziert Können“ erscheint ein solches Sollen ohne Können zunächst kaum vorstellbar. Kühler argumentiert jedoch dafür, dass die Beziehung zwischen Sollen und Können eine deutlich komplexere ist, die nicht zuletzt davon abhängt, von welchem Sollen genau die Rede ist, wie das Nichtkönnen der Akteure zustande gekommen ist und worin es genau besteht. Auch die Interpretation des Implikationsverhältnisses ist keineswegs unumstritten. Kühlers Kernthesen lauten dann erstens, dass es sich bei dem Prinzip „Sollen impliziert Können“ nicht um eine begriffliche Implikation, sondern um ein komplexes, genuin normatives Abwägungsverhältnis zwischen verschiedenen Facetten des Sollens und des (Nicht-)Könnens handelt, und zweitens, dass es gute Gründe gibt, auch an nicht erfüllbaren konkreten Sollensansprüchen festzuhalten, ohne dass dies den Adressaten gegenüber unfair wäre. Diese Gründe werden im Rahmen sowohl pragmatischer als auch in einem engen Sinne moralischer und schließlich in einem weiten Sinne ethischer Überlegungen entfaltet.

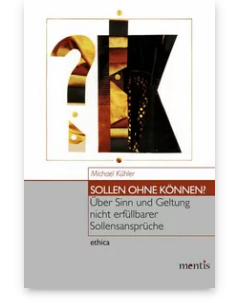

Pages: 285

Seiten

Language:

German

Subjects:

General,

Philosophy

Publisher: Brill | mentis

Series:

ethica, Volume:

21

E-Book (PDF)

Released online: 17 Sep 2013

ISBN: 978-3-

95743-976-5

List price

Paperback

Publication date: 17 Sep 2013

ISBN: $978-3^{-}$

89785-320-1

List price 
For more information see brill.com

Order information: Order online at brill.com +44330 333 0049 | customerservices@brill.com Submission information: brill.com/authors

Titles published by Brill | Fink, Brill | mentis or Brill | Schöningh: +49(o)715413279216| brill@brocom.de 